Caribbean Routes: Ethnographic Experiences, Theoretical Challenges, and the Production of Knowledge

\title{
You must have people to make business: Relations of proximity in small-scale trade in Haiti and the DRC
}

\author{
Felipe Evangelista' \\ Rosa Vieira' \\ 'Universidade Federal do Rio de Janeiro, Museu Nacional, \\ Programa de Pós-graduação em Antropologia Social, Rio de Janeiro/RJ, Brasil
}

\begin{abstract}
This article analyses the everyday activities of female traders in open air markets, houses and streets through a comparative approach based on two ethnographies, one situated in Haiti's Central Plateau, the other in Kongo Central province of the Democratic Republic of the Congo. In both studies, we identify an essential kind of knowledge needed to do business, namely the creation and maintenance of interpersonal relations that help the trader to form stocks, make journeys, guarantee a clientele, loans and financing in settings of uncertainty and economic instability. Simultaneously, we highlight a moral universe that qualifies more and less acceptable ways of obtaining money. In pursuing this comparative approach, we offer an alternative understanding of economies conventionally treated as informal, proposing an analysis primarily focused on the relations of proximity structuring them.
\end{abstract}

Key words: trade; person; money; Haiti; Democratic Republic of the Congo. 


\section{Você precisa ter pessoas para vender: Relações de proximidade no comércio no Haiti e na RDC}

\section{Resumo}

Este artigo analisa as atividades cotidianas de mulheres comerciantes em feiras, casas e estradas através de uma abordagem comparativa entre duas etnografias, uma realizada no Plateau Central (Haiti) e a outra no Kongo Central (República Democrática do Congo). Em ambas as pesquisas, identificamos um conhecimento fundamental para fazer comércio, o qual consiste em criar e manter relações interpessoais que ajudam a formar estoques, garantir clientela e viabilizar deslocamentos, empréstimos e financiamentos em cenários incertos, de muita instabilidade econômica e em constante transformação. Por outro lado, assinalamos também um universo moral que qualifica as maneiras mais ou menos aceitas de se conseguir dinheiro. Através deste enfoque comparativo, oferecemos uma compreensão alternativa às economias convencionalmente tratadas como informais, sugerindo uma perspectiva centrada, sobretudo, nas relações de proximidade que as estruturam.

Palavras-chave: comércio; pessoas; dinheiro; Haiti; República Democrática do Congo. 


\title{
You must have people to make business: Relations of proximity in small-scale trade in Haiti and the DRC
}

\author{
Felipe Evangelista \\ Rosa Vieira
}

\section{Introduction}

This article is based on two research projects, one in Haiti, in the commune of Belladère on the border with the Dominican Republic, and the other in the Democratic Republic of the Congo (hereafter DRC), between the city of Matadi and the villages of the Mayombe forest in Kongo Central province. Our studies involved accompanying female traders in their day-to-day activities of buying and selling goods, on their travels and also within their houses. In Haitian and Congolese marketplaces, the relations between buyer and seller may be anonymous, but may also be (and often are) highly significant. Transactions of money and products enable the development of mutual obligations and trust between people. ${ }^{1}$ Our overall objective, therefore, is to contrast the definitions and explanations given by the traders themselves concerning their own routine practices and activities, seeking to provide a comparative description of a specific kind of expertise shown by these women in their creation and maintenance of relations of proximity.

While a substantial portion of anthropological studies of the economy seek to incorporate the formulations of professional economists and the institutions where they work (Neiburg 2010), here we propose an analysis centred on another kind of specialist, namely the market women themselves. Our aim is to comprehend what their expertise involves, a shared knowledge, partly standardized yet highly adaptable to new situations. This malleable expertise is encountered in the fluency of speech and gestures on the roads, in the warehouses and on the market stalls. Certain standardization indicate a shared know-how, at the same time as the capacity to improvise is essential.

We identify categories linked to a form of 'knowing' how to relate, maintain and multiply interpersonal relations, not within larger groups, but mainly one-to-one. As a general skill in relations between persons, some degree of overlap exists between trade and life - an overlap between instrumental relations, friendship and kinship. Fed by the need for credit and by the circulation of produce, interpersonal relations are fundamental to the flow of money, goods and other essential resources. At the same time, the potential for conflict is ever present, which partly explains the traders' endeavour to multiply their relations. The dynamism of the trade that we identified in the Plateau Central (Haiti) and in Kongo Central (RDC) can also be explained, among other factors, by the fact that relations change (sometimes breaking definitively) and people seek out other relations, other circuits, and other places to buy their stocks and to sell their goods.

The comparative perspective proposed here differs from previous comparisons between the Caribbean and Africa, such as the model of surviving cultural traits advanced by Herskovits (for example, 1937), the cultural studies discussions (Gilroy 1993) and the analysis of beliefs and religious aspects between Haiti and the Congo (MacGaffey 2009). Although our work is based on ethnographies produced in localities with distinct geographies and histories, these were compared through various inter-related aspects that guided our inquiry.

\footnotetext{
1 We maintain a critical distance, therefore, from the hypothesis of "money-as-acid" perceived to corrode relations, an idea widespread in the social sciences, as Bill Maurer (2012) has argued.
} 
First, both Haiti and the DRC are countries marked by the presence of international NGOs, agencies and organizations linked to the field of so-called humanitarian aid, an apparatus that configures forms of government typical of situations labelled as emergencies, subject to cycles of crises (Fassin \& Pandolfi 2010). Consequently, both are defined as places of 'lack,' 'underdevelopment' and 'unemployment.' The metaphor of absence pervaded and still pervades academic analyses of Africa in general (especially the DRC) and Haiti. Achille Mbembe (2001:8), for example, points out that social theory discusses Africa via the notion of lack and, in this sense, the analyst's task becomes one of seeking explanations for such absences. The fundamental point of Mbembe's argument, which applies equally well to Haiti, is the need to avoid the idea of Africa as a "dark cave" (Mbembe 2001:6; also see Roitman 1990). Our comparative proposal explicitly eschews descriptions based around the idea of lack, which envisage popular trade (whether fairs, markets, sidewalks, streets or itinerant trade) as an anomaly, or a chaotic and destructured proliferation, the outcome of a lack of regulation and order imposed by public authorities. So while it is not our intention to describe this trade in terms of what it is not, we also avoid a brand of romantic optimism that, as James Ferguson (2006:10) emphasizes, treats negative descriptions of Africa as the product of Western fantasy. We cannot lose sight, he argues, of Africa "as a place-in-the-world," with particular inclusions and exclusions in a neoliberal global system that defines the varying degrees of uncertainties and instabilities in people's lives. The question, though, is identifying the forms assumed by the practices and vocabularies of the female traders in everyday situations affected by wider political-economic projects, as well as encountering possible intersections between these forms that allow us to suggest other ways of comprehending those activities treated as 'informal.'

This first aspect leads us to the second. The turbulent character of our research contexts is partly due to the scarcity of full-time jobs with stable wages. As a possible correlate of the rarity of full-time employment, small-scale trading seems to be one of the main self-employment solutions among the working classes. Even in the capital cities, Port-au-Prince and Kinshasa, there are very few formal employment positions, but there are many small jobs, "income-generating activities" (Hart 1973), to which people can dedicate themselves simultaneously, combining small and diverse sources of income. Along with the phenomenon of pluriactivity (originally formulated by Hart 1973), money flows in these non-wage economies tend to be highly irregular and accompanied by a proliferation of different forms of debt and credit, as well as small services, small business deals and small profits made through a continuous fractioning of goods (Neiburg 2016). In these universes, the generalization of selling as a practice extends to the most varied things. Objects, food, services always have a sellable potential, just as diverse spaces can become sales points (houses, streets, backyards, workplaces, roads, paths, crossroads). Money itself is also sellable. ${ }^{2}$ The commercial practices analysed here emerge as a zone of invention in which initially original and creative solutions can acquire typical, shared forms.

The third point of approximation worth emphasizing is that most of those working in small street trading in Haiti and DRC are female. According to MacGaffey (1987), since restrictive laws are not in force in the "second economy" and educational qualifications are not required, women do not need to overcome the same barriers as those found in the formalized labour system, such as regulations and educational requirements, which allows them to become wealthy independent of men (p. 165). Traders in the city of Matadi (Kongo Central) remarked that having a daughter is good not only because she will help in domestic activities, she may always sell something. Diverse academic works have shown how the division of functions between men working the land and women selling its produce is normatively (though not exclusively) and historically deeprooted in Haiti, preceding even the foundation of the country and the abolition of slavery (Herskovits 1937,

\footnotetext{
Especially in border zones populated by professional money dealers, physical banknotes are exchanged both for different currencies (the Haitian gourde for the Dominican peso, for instance, or the Angolan kwanza for the Congolese franc, or in both cases converting to the ubiquitous US dollar) and for the promise to return the money with interest at a later date. In the latter case, the moneychangers operate as moneylenders. Although there are people specialized in selling money, it is also sold occasionally by people with other primary occupations.
} 
Lowenthal 1987, Mintz 2010, Garrigus 2006). ${ }^{3}$ For the traders interviewed over the course of our research projects, doing business is a common and socially acceptable form of seeking a living, enabling a greater independence from men and the sustenance of the house when there is no husband or when the husband is not bringing in sufficient money.

Recognizing the cultural and historical idiosyncrasies of the regions where the ethnographic studies were carried out, the points highlighted seem to us persuasive enough to legitimate the comparison proposed here. The heuristic potential of this comparison will be tested through the material taken from each context. However, the first difficulty we faced was which concepts we should use to describe the activities of the female traders observed during our fieldwork. In the first two parts of the article, therefore, we discuss native categories, incorporating them as concepts and seeking to make intelligible the understandings of the traders themselves concerning their practices. Our aim is to specify and contextualize what we have thus far generically called trade. ${ }^{4}$ Each section is also dedicated to analyzing the vocabulary and constitution of commercial relations, in order to discuss the knowledge mobilized to obtain and maintain people (whether suppliers and clients, or other people with whom business partnerships are forged). Next we turn to situations in which people do not act according to the expectations of others, revealing a moral universe that qualifies actions and behaviours.

\section{The concept of lizay and the density of relations in Haitian popular trade}

In Haiti, the research was concentrated in small provincial towns and rural settlements in the region spanning the border between the Haiti's Plateau Central and the San Juan Valley in the Dominican Republic (DR). These are localities dynamized by flows of people and produce. The second most important route connecting the national capitals and largest cities on the island, Port-au-Prince and Santo Domingo, passes through this border area. Part of the research was undertaken in Dominican territory but usually following Haitian female traders in their frequent border crossings. It is their practices and dialogues to which we refer below.

Among the many different forms of engaging in trade in Haiti, the most basic distinction made by traders is between those dedicated to 'trading' (literally, 'doing commerce,' fe komès) and those who have just 'come to sell' something, typically a portion of their family agricultural production. It is one thing is to 'sell' (vann) a harvest. It is quite another to make a living from the incessant activity of buying and then reselling in search of 'small profits' (ti benefis), immersing oneself in a routine that may include travelling long distances to find suppliers of a specific product or to reach places where people pay more for a given kind of merchandise. According to these terms, here we focus on 'trading' properly speaking.

There are two fundamental prerequisites to trading in Haiti. The first is capital, without which it is impossible to stockpile goods for resale. In the absence of hard cash (which undoubtedly was and continues to be deemed preferable: see, for instance, Métraux et al. 1951, Mintz 1964), this capital assumes other forms, like advance receipt of goods to be paid for after sale, loans from relatives or moneylenders, rotating credit groups, among other sources (Evangelista 2019). All the alternatives to hard cash require the establishment or maintenance of interpersonal relations with people (or groups of people) who help supply the necessary capital. We thus arrive at the second prerequisite to doing business, invariably cited by the traders and discussed in this section of the article: lizay.

\footnotetext{
3 Selling (and also to a lesser extent buying) foodstuffs is a preeminently female task, to the point of it being shameful for a man to be seen selling agricultural produce, like a morally dubious intrusion in “women's affairs” (Bazabas 1997:19-20).

4 The parts of the text referring to Haiti cite terms in Haitian Creole. In the case of the DRC, most of the terms cited are from Lingala. When terms from French and Kiyombe are cited, we indicate their linguistic sources. Lingala and French, as well as Kikongo, are used in Matadi where a 'Lingalazation' of Kikongo has been identified. Kiyombe is spoken especially in the Mayombe forest villages.
} 
Lizay is a frequently employed concept that names an oral and dialogical skill, a form of addressing others. In the context directly related to trade, the idea of lizay appears as the art of speaking well to people. This entails being respectful, non-invasive, while transmitting enthusiasm, knowing how to greet (salye) people, or having a 'sweet tongue' (bouch dous). As one female interlocutor defined it, "lizay is the capacity to speak to other people in such a way that they like you." It comprises a specific form of being kind and agreeable, a kindness that consists mainly of recognizing the other, their position, their needs and difficulties. Lizay involves knowledge of the codes, allowing those possessing it to make their needs and demands known in a way that ensures they encounter the least resistance possible. Lizay is something one has: someone may have more or less of it, or none at all.

It is always a criticism to declare that so-and-so has no lizay: it means that they fail to properly recognize the needs and difficulties of others, the people with whom the person is dealing. Not having lizay is dangerous, whether one is interacting with suppliers, buyers, moneylenders, transporters (from truck drivers to motorbike taxis), Dominican guards posted on the border, owners of depots and other storage spaces, or other female sellers. Use of this concept is by no means limited to trade, it applies to many areas of life. However, the fact that market women see this skill as something necessary to succeed in commerce provides an insight into key aspects of the environment in which these women operate.

In Haitian Creole, no distinction is made between buyer and seller: both partners are called by the same name, even if in a concrete situation, one of the parties is just selling without buying anything or vice-versa. Following Paul Moral (1960), Sidney Mintz (1961) made this fact more widely known to the Anglophone academic audience, describing the pratik relation in Haitian markets. This word reciprocally names both buyers and sellers, so long as the relationship between the two women enjoys a certain temporal stability. As Mintz notes, the emphasis on reciprocity is given by the language itself.

When two pratik meet in the market, the interaction between them typically includes salutations, questions about each other's family, swapping news about their respective neighbourhoods, as well as, of course, the purchase itself. Describing how this type of connection emerges in Haitian markets, Mintz (1961) writes that everything begins with a conversation in which, "if the seller likes the buyer's manner," the seller makes a very reasonable offer, demonstrating her desire to invest in the relationship. Although his study primarily explores the rationality informing this personalized economic relationship, it is evident that the flows of goods and money are also accompanied by affects. Affection is indissociable from the development of the relationship, mediated by codes of showing respect and forms of etiquette. Their absence can interrupt this flow. If a particular product is in short supply, for example, the producers may refuse to sell it to unknown buyers who appear with ready cash, preferring to wait for a trader with whom they already have an established bond. Sometimes, therefore, access to particular stocks depends entirely on lizay, which also influences credit arrangements, as seen, for instance, in the care that each pratik takes to avoid 'breaking' (kraze) their partner financially.

The arrangements these preferential relations create are dynamic. Recognition of a pratik relation involves affirmation of a stronger bond, compared to which other relations appear more trivial. It is a privileged bond and like any privilege can be challenged and changed. Maintenance of a pratik bond comes with a cost for traders. A trader called Madame Jislen, for example, mentioned the need to give small 'presents' (kado) to clients when they are going through difficult moments without the money to buy anything. ${ }^{5}$ In such cases, she gives small amounts, which at least will do for that day.

5 To protect the privacy of those with whom we lived during our fieldwork, we have not used people's real names in this article, neither for the Haitian data, nor for the DRC. 
These gifts are a way of investing in the relationship with the client in question. In her own words, she does this "because of lizay," a point that adds another layer to its definition: more than simply the ability to perceive and acknowledge the situation experienced by the other person, having lizay also implies caring for this person when he or she finds herself in trouble. Madame Jislen considers it necessary to give not just to those presently unable to buy, but also when a pratik who took out debts with her some time ago finally pays her back: "you need to give a little present, a spoonful of sugar ...because of lizay."

Here, in exploring the concept of lizay, we attempt to capture synthetically some of the micropolitics involved in the multiple relations each trader needs to maintain. While pratik is a specific relation of purchase and sale, a range of other interpersonal relations also prove fundamental. Each trader establishes and cultivates relations without which it would be very difficult, if not impossible, to access means of capitalization (from informal moneylenders, who tend to personally know the people to whom they entrust their money, to friends and family with the financial capacity to support someone else's business), transport, storage and accomodation/hospitality, or even to guarantee her own safety. Trading demands travel and it is common - though not obligatory - for traders to personally know both truck drivers and motorbike taxi drivers who transport their merchandise.

Mobility requires more than just pathways to flow along. It also needs stopovers, both for the trader herself when the distance travelled requires her to stay overnight, and for her stocks. As well as the depots located close to the markets, traders make use of other spaces such as collectively rented rooms and the houses of other people (rather than her own house, considered a dangerous option best avoided). Houses strategically located near to roads, for instance, or on the border with the Dominican Republic, are especially favored. For traders, it is important not only to know the depots and people responsible for these spaces, but also to have friends along the routes one wishes to travel. ${ }^{6}$ Alongside the buying and selling partnerships called pratik, there are many others, generally referred to by more inclusive terms, such as 'friend' [zanmi], 'partner' [patnè] or 'my person' [moun pa-m].?

Though necessary, these partnerships can also entail financial losses, as in the following scene. A woman called Maudeline went to the Kwa Fè market carrying three bunches of bananas, tied in a large cloth sack, harvested from her son's garden. As she was approaching the market, she noticed Madame Lionel, a madanm sara (a term used by long-distance traders, also the name of a bird) from Lascahobas. Madame Lionel was sat at a strategic spot where the earth track joined the asphalt road, a point of access to the market difficult to avoid. Maudeline tried to pass by unnoticed, not because she disliked her, far from it. She was unsuccessful, though: Madame Lionel saw her from afar and called her over. Maudeline could not ignore her. She would have found it easier to "make a price" ( bargaining room was much narrower given the length of their partnership.

Madame Lionel had been doing sara for years, mainly trading bananas. Maudeline, still a young mother looking to establish her own circuits, was welcomed by Madame Lionel both in her house in Lascahobas and in the room she rented in Port-au-Prince. Madame Lionel had already visited Maudeline's house in the Lospwèt zone (returning visits is an important show of recognition). "She was my pratik," Maudeline told me as she explained why she had tried to avoid her, a response that initially seemed to me both enigmatic and counterintuitive. Since I had failed to understand her point, she repeated her lament in another form, just as counterintuitive for me: "it's because we're friends" (nou zanmi).

\footnotetext{
6 As a valued social skill, lizay undoubtedly helps make friends, but one thing does not necessarily imply the other. The parallel with the idea of 'sympathy' can help elucidate this point: while people generally prefer to deal with others who are sympathetic towards them rather than unsympathetic or even hostile, this does not mean that sympathy is a criterion necessary for friendship. It is perfectly possible to have antipathetic friends.

7 This complex and fascinating term would require another article to be properly unpacked. Dalmaso (2014) brings important data and interpretation to it, though using a different (and synonym) form, more common in the area where she conducted her fieldwork, moun mwen.
} 
The two women greeted each other affectionately and Madame Lionel then asked to see the merchandise Maudeline had brought. Cornered by her friend, Maudeline declared that the bananas were not hers, she was selling them for a neighbour. This lie was credible. It is common in the neighbourhood for people to sell produce belonging to someone else without taking any kind of commission. Maudeline herself did so now and then, but that day the load that she had brought to market came from her own son's garden.

Madame Lionel examined Maudeline's load and offered her 210 Haitian dollars (dolà) for the lot. ${ }^{8}$ Maudeline replied, "my dear, you know I want to sell them to you, but I need to check with the owner first." Next to where Madame Lionel was sat were various other sacks already purchased by the madanm sara that morning. Maudeline left her sack alongside the others and left to wander through the market, as though she were heading off to consult somebody. She waited about 40 minutes before returning with the news that the supposed owner had considered the offer too low and told her not to sell for anything less than 250 dolà. Madame Lionel replied: "So you're going to tell him that bananas aren't selling like that, you managed to sell for 230 and he should be happy because it was an excellent deal." As she said this, she was already taking out and counting the money, handing it to Maudeline, who had no option but to accept it. Remaining cheerful, she thanked Madame Lionel before taking the money, saying in a complicit tone that she would persuade the owner to accept 23o dolà. Her own estimate was that had she traded with an unknown madanm sara, she would have turned up asking for 300 , and could have eventually been paid as much as 270 dolà. At the exchange rate at the time, this difference of 40 dolà (or 200 gourdes) between what she imagined that she could have received from a stranger and what she ended up receiving from her pratik was equivalent to around $U \$ 3.20$, a substantial amount for her. Though disappointed, she did not let her mood show. She resigned herself to the situation with a smile on her face, treating her friend well, even though she had cost her money. She argued that it was necessary to maintain good relations even when they are disadvantageous, "since tomorrow nobody knows."

\section{Knowing vanda bien and having persons to trade with}

The everyday practices of traders and the descriptions of these practices observed in some localities of Kongo Central (DRC) are very similar in diverse respects to those described above for Haiti. While the same categories may not say the same things in different places, distinct categories in localities far from one another may very well reference similar meanings. In this section we explore ethnographic situations observed on the other side of the Altantic with the intention of considering the Haitian trade discussed above in a comparative perspective.

Situated in the province of Kongo Central (DRC) on the border with Angola and along the shore of the Congo River, the city of Matadi concentrates trade circuits of different scales. ${ }^{.}$These include the flow of produce from Angola to the DRC, a circuit of goods imported from other countries and unloaded at the river ports, the bulk of produce being sent to the capital Kinshasa, combined with circuits of produce arriving from rural areas, especially villages in the north and east of the province. The ethnographic research was concentrated on the palm oil circuit, originating in villages located in the Mayombe Forest and resold in small quantities in the Matadi street markets.

\footnotetext{
8 The Haitian dollar (dolà) is an imaginary currency, without physical existence, a pure unit of account, used in a scale of five (see Neiburg 2016). Haiti's official currency is the gourde, but people frequently refer to the 'Haitian dollar,' equivalent to 5 gourdes. Thus 210 dolà $=1,050$ gourdes.

9 Matadi has around 300,000 inhabitants and is the sixteenth largest city in the DRC. In the city markets, people mainly speak two Bantu languages, Lingala and Kikongo, sometimes mixing the two.
} 
The research began in one of the city's seventeen markets, a neighbourhood fair that was also called a 'parking,' where people arrived in cars, trucks and motorbikes, coming from rural villages to sell their produce: manioc leaves, coffee, sacks of fufu (dehydrated manioc), kwanga (manioc pulp), bananas, brooms, palm oil and other sundry items. ${ }^{10}$

This is the market in which Ma Henriette runs a méza, a wooden stall, where she sells a variety of products including grains, salt, sugar, powdered milk, coffee, tea, soap, sunflower oil and palm oil. She calls this type of trading vente au detail, "1 'retail sale,' whose main characteristic is the resale of produce in small amounts, items able to be broken down into various measures. Ma Henriette and other détaillantes differ not only from the "people of the village" (batu ya mboka) who come to sell their harvests in the city, but also from the wholesalers who sell imported products in large quantities in internationally standardized measures ( $25 \mathrm{~kg}$ and $50 \mathrm{~kg}$ sacks and 201 or 25 l gallons). As well as détaillantes, they call themselves - and are generically called by others - mamas or mamas ya wénze, 'market women.' To define what they do to earn money, they usually say 'I sell' (nateka), very often without identifying what they sell and differentiating 'selling' (koteka) from debrouille. ${ }^{12}$

On Ma Henriette's stall it was common to hear assessments of whether a certain person knew how to sell or not (koyéba koteka). This is a skill with diverse layers of knowhow, some acquired through day-to-day experiences, others that approximate a relational knowledge (kovánda mbóte or kovánda bien) ${ }^{13}$ that allows the trader to obtain and maintain clients and supliers. Among the female market traders, however, the notion of 'knowing' or 'not knowing' how to sell emerged initially in reference to the practice of handling measures and products.

The peak hour of Ma Henriette's stall is between 8 am and $10 \mathrm{am}$. Arriving at the stall, the pastor's wife asks for two cups of rice, a mug of sugar, and 'a coke' of palm oil. Ma Henriette takes a glass Coca-Cola bottle and fills it with palm oil, then shouts out to her niece, Zoe, who slowly makes her way to the grains to fill the cup of rice. The client complains that Zoe is not filling the cup properly and tells Ma Henriette "she doesn't know how to sell" (ayeba te koteka). In retail sale, it is very important to know how to manage different types of measurement: $200 \mathrm{ml}$ glass cups, plastic mugs, bottles, spoons. These need to be filled according to the pace of demand and to the precise limit so that there are no losses for the seller, but equally so that buyers do not complain.

"Knowing how to sell" does not depend solely on the use of one's hands, though. It requires a certain quickness of mind in calculating prices and change, counting and managing the money earned during the day. In one morning of sales, Ma Henriette earns somewhere between 100 and 200 franc congolais (between 60 and 115 dollars), which she uses to cover household expenses and restock her stall products. She spends some time at the market listing the products that have sold out, thinking about the suppliers with whom she has debts and planning how to pay them so she can take out new debts without jeopardizing her relationship with them. When speaking about her suppliers, there were some who Ma Henriette considered to be "her people."

This expression, "my person" (mutu na ngai) was associated in Matadi with the terms camarade (comrade, pal) and ami (friend) in French. It was also used in situations that made explicit the transaction of money and/ or products, employed to refer topersons with whom one engages in a commercial partnership (e.g. supplier

\footnotetext{
10 The author Rosa Vieira spent the first phase of her fieldwork, lasting three months, selling alongside a market trader on her stall.

11 Ma Henriette used French terms to refer to her trade, which forms the final stage of a distribution chain.

12 The verb in French, se débrouiller, signifies to cope, to manage, to find a way. Gauthier De Villers et al. (2002) and Sylvie Ayimpam (2014) include the commercial practices in the DRC as part of something more general that they call an économie de la débrouille. In the dialogues of traders in Matadi, however, being in the débrouille is different to selling (teka). Asked whether her husband also sold produce, one female trader replied: he doesn't sell, he's in the debrouille (ateka te, aza na débrouille).

13 In Lingala, kovánda can also be written as kofánda. The expression is also very often pronounced along with the French adjective bien (kovánda bien).
} 
and client). It was equally used when someone had a direct interest in asking another for something ("give me money, you are my person"). Just like lizay, "my person" is not exclusive to the commercial universe but the ability to "have people" is inherent to "knowing how to sell."

One day as I worked on Ma Henriette's stall, Ma Julie asked for a cup of salt. I leaned over to serve her and filled the cup the way I had learned. But as soon as she saw what I was doing, Ma Henriette intervened: fill it more, put more in, she's "my person," referring to Ma Julie. The relationship between these two mamas had begun with the sale of gallons of palm oil, which later became accompanied by conversations and the swapping of information. They gradually developed a degree of mutual trust, which made them a person to each other, a relational condition that, like any other relation, lacks stability if it is not cultivated through these kind of small everyday acts, such as adding an extra amount to the sold product.

For Ma Henriette, the supplier who is "her person" will understand her situation even when she has no money to pay. Ma Julie added other aspects to define someone who is her person, they "will eat together, sleep together, talk and will also make cop (...). You see how you give me your trust, you won't give it to just anyone. ${ }^{14}$ Her description tells us that an important dimension of the "my person" relationship is mutual trust. And in trading, it is trust that makes partnerships, leaving your money with the other person, making deals in the transactions and negotiating the time period for repayments, an aspect made explicit by Ma Julie when she referred to Ma Henriette: "you see Ma Henriette, she comes every week, she became my person, even when she has no money, I'll give her [the produce] and afterwards I'll get the money. I've become habituated to her. Had I not done so, I would never give her [gallons of palm oil]." The notion of 'becoming habituated' to the other is also an important aspect. In trade, relations acquire trust with the frequency of the transactions. Furthermore, as we have seen, in the same way as pratik, being a 'person' to each other involves a one-to-one relation that requires some degree of reciprocity: you are someone's person if the other is also your person. Like the other suppliers who are 'persons of' Ma Henriette, Ma Julie also needed Ma Henriette to maintain her sales. Despite the delays, she paid her debts, unlike other mamas who vanished or lied. She also sought to maintain her regularity as a client, not passing a single week without buying gallons of oil.

However, one-to-one relations do not involve suppliers and clients alone. Differently to Ma Henriette, Ma Julie travels a long distance each week to buy gallons of palm oil in her home village, located in the Mayombe Forest, some 20okm from Matadi. She "has persons" who help her on her journeys and in maintaining her trade between city and village. When Ma Julie is unable to travel, she will, for example, send money via one of the mamas who undertake this journey constantly with her. She can also depend on "her people" in her village, like Pa Mana, with whom she leaves money in advance for him to buy the gallons of oil. She always explained that she had "many people" because she vánda bien with/in everyone ${ }^{15}$. This expression can be translated as "I relate well" and is also used in conjunction with the verb 'to know' (koyeba). Ma Julie's explanations help us reflect on what this knowledge is.

In the dry season between May and September, it is not easy to buy many gallons of palm oil. It rains seldom, there are less fruits on the palm trees to produce the oil and the price increases. This prompted Ma Julie to turn to sources of income other than her trade in gallons. She began to rent land in another village to plant beans and sell them in the city. Unlike her home village, this was not a place where she had family and people. The first time she went to plant, she slept in the house of the owners of the land she had rented.

\footnotetext{
14 The term cop comes from coopération, engaging in cop means to form a trade partnership. There are various types of cop, such as, for example, when two persons combine their gallons for one of them to take to sell in Kinshasa. Generally these are one-to-one partnerships, between two people.

15 In Lingala, verbs in the infinitive are marked by the prefix ko, kovánda bien.
} 
The second time, the house was no longer available. Ma Julie ended up sleeping in the house of Ma Tania, a young woman she had met only recently. When I asked Ma Julie how she had begun to frequent this house, she replied: "I know how to relate (nayebi vánda). I make some food. I give a little bit of sugar to people, we get on well. (...) I can relate (navandi bien) with anyone. You need to know how people behave."

As we can see, Ma Julie uses the term vánda, which has various senses in Lingala. Two in particular are important to understanding the meaning of relating with another. ${ }^{16}$ It can be used in the sense of dwell (where do you live? ovanda wapi?) and it may be said that "knowing how to vánda" also involves knowing how to live with the other. As Ma Julie makes clear, it presumes knowing how to share food and a space, whether a house, a market, or a neighbourhood. To some extent, it would even be possible to conceive the idea as knowing how to dwell in the other. Because knowing vánda bien requires comprehending the other, to the point of putting oneself in their skin, understanding the difficulties that the other person is facing. Vánda is also used to refer to the verb sit (sit on the chair! vánda na kiti) and we can venture the idea that knowing how to vánda also entails knowing how to sit with the other, since the act of sitting is closely associated with conversation. In Lingala, for example, before starting a conversation, people will usually say "come, let's sit" (yaka, továnda na biso) or "do you want to come over to the house? we can sit and chat" (okoya na ndako, tokovánda, tokosolola). To sit with someone is to share a moment with them in order to exchange, and this exchange very often refers to commercial activity, whether maintaining partnerships or creating new ones.

This everyday knowledge of relating/dwelling/sitting with/in the other, linked to the experience of sharing food, money, information, gossip and spaces (like the market, neighbourhood, depots and roads), ensures making, obtaining and maintaining "one's people," so central to dealing with the difficulties faced by traders in their activities. But there are those who do not know how to vánda or, as people say in Haitian trade, who have no lizay, provoking conflicts, which reveal a moral universe that prescribes more or less accepted ways of behaving in the quest to make money.

\section{A trader without lizay}

A trader called Tina had for some months been smuggling beer, rum and cigarettes to sell in the Dominican Republic. She usually undertook various journeys, entering and leaving constantly, bringing a little produce each time, hiding packs of cigarettes (worth 30 dolà each, around U\$2.40) and small bottles of rum (sold in Haiti for between 15 and 18 dolà, around U\$ 1.20-1.45) underneath her clothes. On each trip, she managed to bring concealed at least eight small bottles of rum and a larger quantity of cigarette packs, relatively expensive items that practically doubled in price on crossing the border to the Dominican Republic.

Tina took them to a friend's house, accumulating a substantial quantity to sell in one batch to a Dominican dealer, which for her was safer than selling retail herself in the streets of Elias Piña. One day, two guards from Dominica's border security followed her to the front of the house she was using as a depot, where they stopped and searched her. Caught red-handed, not only was the merchandise on her person seized, but also the goods she had brought previously, stored in the room. The setback was huge: the lost batch was worth more than 3,500 dolà (equivalent to almost $\mathrm{U} \$ 300$ at the contemporary exchange rate). For a trader like Tina whose finances were precarious, it was an extremely hard blow from which it would take her months to recover.

16 The other uses of the term vánda: vánda na yo (shut up, enough, used during rows); avánda na ye (to say that the person got comfortable, like a trader who used the term to refer to a young woman who had not paid her: avánda na ye, azofuta te, she 'got comfortable,' she 'stays sitting,' she does not pay, she 'became slack'; vánda na ndâko (in the sense of resting at home, relaxing, in contrast to selling or working). 
While people took pity on her plight, several pointed out that the misfortune was at least partly Tina's own fault. She had always complained that the Dominican guards were thieves - an opinion by itself widely shared. However, the vast majority of traders who smuggled contraband into the Dominican Republic recognized the need to keep these guards happy, 'helping them,' which they did through small bribes. The standard amount was 100 pesos (a little over $\mathrm{U} \$ 2$ ) but, depending on the volume of goods, it was prudent to give better 'presents' (kado). The fact that such prudence is a recognized and shared way to proceed highlights the limits between, on one hand, a sociability that demands the sensibility to perceive the other, where some degree of flexibility and improvisation is needed in response to concrete situations, and the existence of a set of shared codes, providing typical solutions to potential clashes. But Tina did not want to know: she was poor, she had her three children to care for, she needed the money, and she felt that she owed nothing to those 'thieves.' As one of Tina's aunts explained to me:

Every week Tina passed the border guards without ever giving them money, not once, nothing. She doesn't think that they have a family too, they have expenses, she doesn't want to see their side or contribute anything, she just complains that they're thieves, she doesn't owe them anything... Now, look, with twenty dolà today, ten dolà the week after, she would have avoided this, but, out of stupid pride, she took a much bigger hit.

But wouldn't the guards who found the contraband not have confiscated it anyhow? I asked.

Of course not! They know who brings in contraband, if they let us pass it's because they choose to let us pass... It was a young man called Montero, he was annoyed with her because she never gives anything and he took revenge. He didn't go after her himself, he waited until he was off shift and passed on the information to two guards who had arrived from the capital, telling them to search her, and the rest we know... Tina has no lizay, her aunt lamented.

Engaging in trade across national borders involves dealing with forms of regulation and control to which many of the activities of female traders in Haiti are subject. Certain kinds of knowhow, acquired in conversations and through experience, enable them to be circumvented. In Tina's story, it was necessary to have lizay, perceive the needs of others, recognize the place occupied by the other with whom one must deal, as well as recognize that if this other feels overlooked or disrespected, he or she may cause you harm, make your way more difficult. Reciprocally, it also implies possessing the skill to make the other feel compelled to perceive, recognize and respect your own place.

For a woman like Madame Jislen, therefore, paying your debts on time is also a question of lizay. The parallels with the idea of vánda bien cited earlier are clear: in both cases, the other person's needs must be recognized while ensuring one's own are met, caring for a relationship that may prove important in the future. In stressing the importance of paying on time, Madame Jislen recognizes that this is essential to being able to continue to take out new loans without a creditor refusing. As she operates mostly by consignments, a single default could jeopardize her entire future business. At the same time, you also have to recognize the situation and urgent needs of those people who have already loaned to you (whether in money or in goods), knowing that a delay on your part may jeopardize other people's operations where they also have deadlines to meet. She does not think it fair to setback the life of someone who advanced her own, and would feel deeply ashamed were she to do so. Madame Jislen prefers to complicate her own financial situation with new loans to cover a previous one than leave the other person waiting, failing to meet an earlier agreement.

As a moral principle that regulates codes of conduct and that not everyone manages to observe with the same zeal, the concept of lizay offers important parallels with our other ethnographic context in the DRC specifically in the implications of the concept of "my person" and the idea of "dwelling in the other," which valorizes the capacity to understand the moment and other people's problems. Lizay refers to the observation 
of specific codes of conduct, not only as a form of etiquette, but also as a valorization of empathy, the capacity to perceive the other. The small conflict narrated above indicates the potential damage caused by insufficient empathy, which, as we have seen, is necessary even in the interactions with supposed 'thieves.'

\section{Eating the other's money}

Between Matadi and the villages of the Mayombe Forest, the motives for conflicts between female traders are diverse: unpaid debts, people who engage in cop and lied to their partner, ${ }^{17}$ traders who steal others' clients, theft of products, envy, and so forth. In these situations, insults are hurled between the parties involved: bad behaviour (comportement mabè), a false and deceitful person (aventurier). ${ }^{18}$ bad hearted (mutema mabè), a sorcerer (ndoki). An important term to understand these conflicts is the verb 'to eat' (kolya) which can be used to refer to eating money, eating people (referring to both the sexual act and sorcery) and eating food. ${ }^{19}$

The expression 'to eat money' (kolya mbongo) is significant in terms of our comprehension of forms of relating and conflicts, whether in trading or in other areas of life. To eat money is used to refer to the act of spending, using the cash one has in hand. Very often it has a negative moral connotation: the expression may signal that the money was used in one way when it could have been better used in another: it was spent, rather than invested. Everyone is eating their own money all the time and also eating other people's money. Selling requires travelling and it is common to send money via another person, to give money to one person here, pick up money from another there, leave a debt with the neighbour, accept that they owe you.

A trader like Ma Julie always has many people with her money. As described earlier, she leaves money with people in the village to buy gallons of palm oil for her. Although she knows that there may be some delay in returning the gallons, she prefers this arrangement, thereby avoiding, as she says, eating her own money instead of investing. But there is always the risk of the money or the gallons not making their way back to her hands.

If the gallon is overdue, this does not mean that the person ate the money. They eat it when they disappear, when they fail to give another deadline to pay, or when they lie, saying that they received a smaller amount than the actual money given. The problem is not the debt but the ignored debt, when the debtor shows no intention to pay it back or does not recognize its existence. It is then that people say "he ate my money." This is when the expression acquires a negative sense, used, for instance, when a conflict breaks out at the weekly market held in a village in the Mayombe Forest.

This market attracts many people from nearby villages, occupying the length of an entire dirt road. At one end are concentrated the wooden stalls, at the opposite end the parking lot filled with the trucks ready to transport produce to the cities of Matadi and Boma. Ma Julie usually picks a spot in front of an empty house whose rooms are rented by the traders as depots. In the external area of the house there were clusters of oil gallons, sacks of fufu and bags of charcoal, separated carefully by trader. Shouting began. Ma Eva and Ma Julie were surrounding a young man on the right-hand side of the house, accusing him of owing them gallons (three and two, respectively). The tall young man was defending his actions. He told Ma Julie that he had returned the money to Cesar, her brother. Ma Julie immediately shouted out, calling her brother. Cesar denied receiving the money and the discussion continued. I asked another young woman from the villlage what was happening and she said: "he ate it," making a gesture of wiping her hand across her lips, and said "it's gone!"20.

\footnotetext{
See note 14 .

8 This is different to the meaning identified by MacGaffey and Bazenguissa-Ganga (2000) who refer to partir à l'aventure as a notion related to immigration and the activities associated with this experience.

19 To eat is also used in Kiyombe, the Bantu language spoken in the Mayombe forest, associated with money: kudya zi mbóongo.

20 This remark 'he eats' was pronounced in Kiyombe (kadidi), the language in which the expression to eat money (kudyá zimbongo) is also used.
} 
As people explained, this gesture expresses the act of "finishing eating and cleaning one's mouth." Without doubt, if the money had not returned to Ma Julie, it was being used in other spheres and circulating among other people. But the gesture shows a shared understanding that if someone eats your money, it has vanished for you, it will not come back, at least not very soon. To eat, not just money but food too, can be understood as materially finishing something, but this is not necessarily negative. In reference to eating food, for example, the gesture is only used if the person eats food they should not have. Thus there is a negative moral connotation when the verb is used in conjunction with the gesture: it indicates someone who ate food secretively and was discovered: we only see them "cleaning their mouth." In other words, to eat is negative when it is done for one's own benefit and harms others, as in the case of the young man who ate Ma Julie's money.

The row in the middle of the market was a way of pressuring the man to return the money by embarasssing him publicly, showing that he was an untrustworhy person who did not think of others - thus he did not know how to vánda bien. People eating the money of others the whole time exposes a universe in which money circulates, mediating the relations needed to obtain and sell products, connecting persons through bonds of debt. Very often, unpaid debts lead female traders to re-evaluate and transform their commercial partnerships.

\section{Conclusion}

Analysing the small-scale trade made in Haiti and the DRC, it could be argued that the huge majority of female traders operate as "one-woman businesses," in the sense that each woman generates her capital by herself at her own risk, just as she decides herself what to buy and from whom, where to sell and how to transport the goods. ${ }^{21}$

Each trader establishes her own circuits, just as she maintains her own array of relations that assists her to travel. However, the individualism linked to the high level of autonomy entailed by the logic of selfentrepreneurialism coexists with and is informed by one-to-one interpersonal relations in all points of the chain of distribution. In both ethnographies, partnerships abound for trade with multiple aims: forming a relatively stable clientele, accessing producers and their produce, loan schemes, the dispatch of money locally to save time and money on trips, safeguarding against the confiscation of merchandise, among many others..$^{22}$

These arrangements are dynamic: new connections are made, remade and unmade continually, some partnerships create deep proximities and acquire a long-term and stable form, others are occasional and ephemeral, some can convert into the other kind and vice-versa. This dynamism requires creativity and the capacity to improvise in adverse situations. But it is also impossible to navigate in trade without ever knowing the codes, practices, gestures and forms of relating to people, which constitute shared and evaluated knowhow, as we have shown in the analysis of the notions of lizay and vánda bien. This dynamic recognizable in both universes, despite their distance from each other, may also encounter parallels around the world, as a reorientation of the life of the poor under neoliberalism, especially in contexts subject to regular economic crises $^{23}$. The identification of an element of individualism typical to the logic of self-entrepreneurialism can and should be complexified by paying attention to partnerships as we have aimed to show ${ }^{24}$.

\footnotetext{
21 It is from this perspective that authors like Mintz (1964) and Plotkin (1989), for example, characterize commercial activity in Haiti as fragmented and individualist.

22 An extensive description of the singularities of these diverse modalities of partnerships is impossible within the limits of this article. For a more detailed exposition in the case of Haiti, see Evangelista 2019.

23 For a global survey of ethnographies describing the strategies used by working classes under neoliberalism, see Ortner 2016.

24 It should be stressed that the traders do participate in collectives like associations, religious organizations or neighbourhood groups. These become spaces for the formation of new trade partnerships and also for a deepening of preexisting ties. For a discussion of trader associations in Ciudad del Este, see Rabossi 2004. In the case of Haiti, the absence of significant professional associations among traders has been identified as a problem, a lack of political articulation (for instance, Plotkin 1989). In the field, though, we observed that non-unionized traders or those not organized collectively in class entities still participated in other kinds of collectivities, especially neighbourhood and church groups.
} 
However, these partnerships qualifiable as 'commercial' - indispensable to the viability of business ventures - are not just utilitarian and instrumental. Possession of lizay or knowledge of vánda bien may be fundamental to trading, but these qualities are not limited to this sphere. On the contrary, we have sought to examine trade not as a closed and self-contained circuit, a self-centred activity, but as an avenue for us to understand how people connect to each other, particularly in contexts where money is sparse and economic instability widespread. Discussing rural settlements in the Brazilian Northeast, Benoit de L'Estoile (2014) emphasizes how, in crisis situations, friends are of central importance. They ensure networks of support when money, though desired, is only fleetingly available. Something similar occurs in the ethnographic universes that we have accompanied. As shown in the transaction between Madame Lionel and Maudeline, the maintenance of long-term trade partnerships is taken to be a safer and more promising path to guarantee the future than ephemeral relations whose momentary profits do not ensure future support. Nevertheless, these relations should not be comprehended from a utilitarianist perspective, given that we are dealing with localities where the "future is irreducible to calculation" (ibid:71) and configures a field of open-ended expectations.

The vast diversity of the ethnographic universes discussed here cannot be disentangled in a few pages. To present this multiplicity, we have introduced concepts that allow us to transit through these relations without needing to immerse ourselves in the singularities of each particular modality - that is, concepts that articulate the capacity to obtain and maintain relations. Lizay and knowing how to vánda bien refer to a capacity, an ability, a know-how, expressed in the forms through which each person positions themselves vis-à-vis others, fundamental to accessing the types of circuit where money circulates in these two universes. When this relational know-how proves insufficient, the person can turn to informal institutions for the latter to penalize defaulters and bad payers. However, the force of the morality in play frequently overlaps with and renders the action of these institutions superfluous.

In Haiti, there are forms of regulating these behaviours that dispense with such institutions. These include stoning the house of the debtor, smearing the person's name in front of other potential creditors, or making demands for payment in person,. The debtor's refusal to pay in the latter case legitimizes the seizure of goods to a value proximate to the debt (see Evangelista 2019). Such methods entail more direct, quicker and sometimes harsher consequences than the processes involving the slow formal justice system. Significantly, the mediation of the latter in conflicts tends to be preferred more by debtors than creditors. In the DRC, people also turn to modes of public shaming that force the debtor to pay the debt or acquire a bad reputation in the places that he or she frequents. Nevertheless, the 'state' (or leta, in the Lingala term) appears as something more commonplace and embedded in commercial practices than a formal institution separate from them. In villages of the Mayombe Forest, the leta can be ordered to capture (kanga) a defaulter, paying money to arrest the debtor and imprison the person if they fail to pay the debt. People also frequently resort to sorcery spells in order to coerce and punish those who have behaved dishonestly. ${ }^{25}$

As we have seen, moral qualifications are mobilized as a form of justice to punish those whose attitudes harm others. At the same time, they also amount to imperatives for the redistribution of money, guiding people who have become rich through trade to meet duties and obligations constitutive of relations of proximity. ${ }^{26}$

In the Mayombe Forest villages, the fear of envy (and the possibility of becoming the sorcery target of the envious) leads the traders, men and women, to conceal how much they are earning, while they also always seek to give a little money or small presents to people close to them, whether relatives, friends or acquaintances.

\footnotetext{
25 For a discussion of forms of justice and sorcery based in an ethnography in Haiti, see Fiod 2019.

26 This aspect is not confined to trade but identifiable also in other activities, as Pierre Minn (2011) has emphasized in the case of Haitian doctors who need to support an entire network of "their people" (moun pa), thus placing themselves in economic difficulties.
} 
Ma Julie, for example, sought to give a little of her money or hide it because, as she said, "you can never know a person's spirit." At the same time, negative moral qualifications are mobilized in reference to the traders who become rich, accused of having made "bad money" either through trips to the cemetery, an act related to sorcery, or through contact with a ngáanga nkiisi. ${ }^{27}$

In Haiti too, becoming rich is morally suspect, readily linked to rumours of sorcery. Likewise, the redistribution of wealth is an important means of forging and maintaining alliances ${ }^{28}$. The very fact that the capital used in trade is frequently stored not in the form of paper money (and less still in bank accounts) but dispersed through multiple credit schemes, which necessarily involve other people, demonstrates how resource management requires sharing and implies interpersonal relations. It comprises a logistical necessity that, simultaneously, is reflected in moral imperatives, in a sociability informed by mutual dependency and the expectation of mutual help.

This interweaving between lives gives the relations woven in the sphere of trade much more density than what would arise from simple exchanges limited to the delivery of goods and the respective payments. Consequently, along side the more technical forms of knowhow specific to commercial activity, the relational knowhow employed by Madame Jislen, Madame Maudeline, Ma Henriette and Ma Julie configure a modality of knowledge also fundamental to their trade.

Received: September 25, 2019

Approved: February 20, 2020

Translated by David Rodgers

27 In Kiyombe, ngaánga nkísi (in Lingala, nganga nkisi) is not a sorcerer and can be seen as a healer. In villages in the Mayombe Forest, people also resort to such figures in search of money and need, in exchange, to sacrifice members of their family. Nkiisi is a proto-Nbantu term widely discussed among Africanists and very often understood as an object with spiritual force or a charm, For a critique of the literature on Kongo culture and the notion of nkisi, see Hersak 2001. Over the course of fieldwork, this term appeared in reference to a power (force, potency) imbued in an object or animal, associated with both the ngaánga and the ancestors.

28 As shown too, in an urban context, by the ethnography of Braum 2014 


\section{References}

AYIMPAM, Sylvie. 2014. Economie de la debrouille à Kinshasa: informalité, commerce et réseaux sociaux. Paris: Éditions Karthala.

BAZABAS, Dingan. 1997. Du marché de rue en Haïti: Le système urbain de Port-au-Prince face à ses entreprises "d'espace-rue". Paris: L'Harmattan.

BRAUM, Pedro. 2014. Rat pa kaka; política, desenvolvimento e violência no coração de Porto Príncipe. Tese de doutorado defendida no Programa de Pós-Graduação em Antropologia Social do Museu Nacional, Universidade Federal do Rio de Janeiro.

DALMASO, Flavia. 2014. Kijan Moun Yo Ye? As pessoas, as casas e as dinâmicas da familiaridade em Jacmel, Haiti. Tese de doutorado defendida no Programa de Pós-Graduação em Antropologia Social do Museu Nacional, Universidade Federal do Rio de Janeiro.

DE L'ESTOILE, Benoît. 2014. "Money Is Good, but a Friend Is Better”: Uncertainty, Orientation to the Future, and "the Economy". Current Anthropology, 55(S9): S62 -S73,

DE VILLERS, Gauthier. 2002. “Introduction”. In: G. De Villers, B. Jewsiewicki, L. Monnier (orgs.), Manières de Vivre. Economie de la "debrouille” dans les villes du Congo/Zaire. Paris: Institut Africain-CEDAF/L'Harmattan. pp. 12-31.

EVANGELISTA, Felipe. 2019. Comércio, Mobilidade e Dinheiro. A busca pela vida no Plateau Central haitiano e na fronteira dominicana. Tese de doutorado defendida no Programa de Pós-Graduação em Antropologia Social do Museu Nacional, Universidade Federal do Rio de Janeiro.

FASSIN, Didier; PANDOLFI, Mariella. 2010. Contemporary States of Emergency: the Politics of Military and Humanitarian Interventions. Pennsylvania State University: Zone Books.

FERGUSON, James. 2006. Global Shadows: Africa in the Neoliberal World Order. Durham \& London: Duke University Press.

FIOD, Ana. 2019. “Feitiço”. In: F. Neiburg (org.), Conversas Etnográficas Haitianas. Rio de Janeiro: Papéis Selvagens, pp. 193-228.

GARRIGUS, John D. 2006. Before Haiti: Race and Citizenship in French Saint-Domingue. New York: Palgrave McMilan US.

GILROY, Paul. 1993. O Atlântico Negro: Modernidade e Dupla Consciência. Centro de Estudos Afro-Asiáticos, Universidade Cândido Mendes. Rio de Janeiro: Editora 34.

HART, Keith. 1973. "Informal income opportunities and urban employment in Ghana." Journal of Modern African Studies, 11(1): 61-89.

HERSAK, Dunja. 2001. "There are many Kongo worlds: particularities of magico-religious beliefs among the Vili and Yombe of Congo-Brazzaville". Africa:Journal of the International African Institute, 71(4): 614-640.

HERSKOVITS, Melville. 1937. Life in a Haitian Valley. New York: Alfred A. Knopf.

LOWENTHAL, Ira. 1987. Marriage is 20, children are 21": The cultural construction of conjugality and the family in rural Haiti. Tese de doutorado defendida na Johns Hopkins University, Baltimore, EUA.

MACGAFFEY, Janet. 1987. Entrepreneurs and parasites. The struggle for indigenous capitalism in Zaïre. Cambridge: Cambridge University Press. .; BAZENGUISSA-GANGA, Rémy. 2000. Congo-Paris: Transnational Traders on the Margins of the Law. Bloomington: Indiana University Press.

MacGAFFEY, Wyat. 2009. “Twins, Simbi Spirits and Lwas in Kongo and Haiti”. In: Linda Heywood (ed.), Central African Cultural Transformations in the American Diaspora. Howard University: Washington DC. 211-226.

MAURER, Bill. 2012. “The anthropology of money”. Annual Review of Anthropology, 34: 15-36. 
MBEMBE, Achille. 2001. On the Post-Colony. Berkeley: University of California Press.

MÉTRAUX el al. 1951. L’Homme et la Terre dans la Valée du Marbial, Haïti: rapport établi par Alfred Métraux avec la collaboration de M. E. Berrouet et du Dr.Jean Comhaire-Sylvain et Mme. Suzanne Comhaire-Sylvain. Documents spéciaux d'éducation no 10 . Paris: UNESCO.

MINN, Pierre. 2011. Where they need me - The moral economy of international medical aid in Haiti. Tese defendida na McGill University, Montreal, Canadá.

MINTZ, Sidney. 1961. "Pratik: Haitian Personal Economic Relationships". Proceedings of the 1961 Annual Spring Meetings, American Ethnological Society: 54-63.

. 1964. "The employment of capital by Haitian market women." In: Raymond Firth and B. S. Yamey

(eds.), Capital, savings and credit in peasant societies. Chicago: Aldine. pp. 256-286. . 2010. Three Ancient Colonies. Caribbean Themes and Variations. Cambridge: Harvard University Press.

MORAL, Paul. 1960. Le Paysan Haitien. Étude sur la Vie Rurale en Haiti. Port-au-Prince: Les Éditions Fardin.

NEIBURG, Federico. 2010. “Os sentidos sociais da economia”. In: Luiz Fernando Dias Duarte (org.), Horizontes das Ciências Sociais no Brasil - Antropologia. São Paulo: ANPOCS/Barcarolla/Discurso Editorial. . 2016. "The true coin of their dreams." HAU:Journal of Ethnographic Theory, 6(1): 75-93.

ORTNER, Sherry. 2016. "Dark anthropology and its others - theory since the eighties". HAU:Journal of Ethnographic Theory, 6 (1): 47-73.

PLOTKIN, Donna. 1989. The International Traders of Haiti: the Madam Sara. Relatório para Economic Commission for Latin America and Caribbean, Caribbean Development and Co-operation Committee. Port-of-Spain, Trinidad, Organização das Nações Unidas (ONU). Mimeo.

RABOSSI, Fernando. 2004. Nas ruas de Ciudad del Este: Vidas e vendas num mercado de fronteira. Tese (doutorado em Antropologia Social). Museu Nacional da Universidade Federal do Rio Janeiro.

ROITMAN, Janet. 1990. "The Politics of Informal Markets in Subsaharan Africa”. The Journal of Modern African Studies, 28(4): 671-696.

\section{Felipe Evangelista}

Federal University at Rio de Janeiro, National Museum, Graduate Program in Social Anthropology, Rio de Janeiro/RJ, Brasil.

https://orcid.org/00oo-0002-7160-0754

Email: felipe.e.a.silva@gmail.com

\section{Rosa Vieira}

Federal University at Rio de Janeiro, National Museum, Graduate Program in Social Anthropology, Rio de Janeiro/RJ, Brasil.

https://orcid.org/oooo-0003-1554-7327

Email: rosacrvieira@gmail.com 